\title{
Orality-if anything, Imagination, resistance in dialogue with the discourse of the historical 'Other'
}

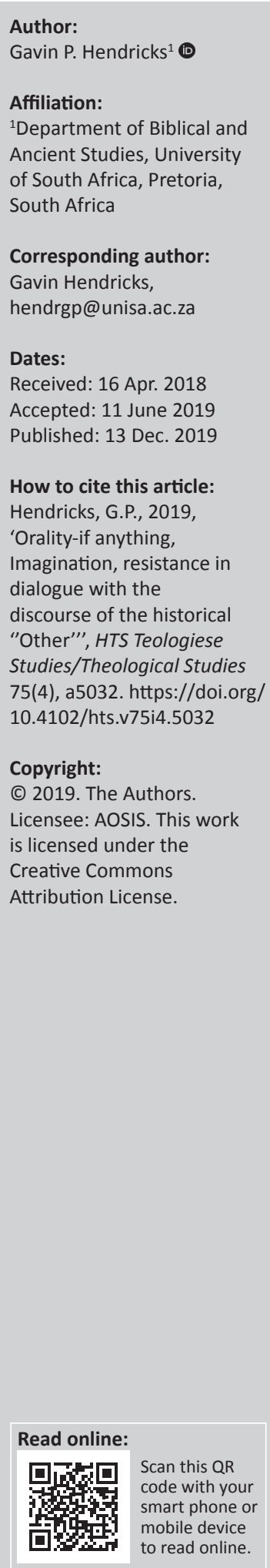

South Africa has a long history of orality deeply embedded in the archival memory of the 'Other' or the history of the poor and oppressed. Their untold stories, undocumented histories with displacing identities are how the historical 'Other' has been perceived by colonialism and the apartheid regime. The 'Other' or primary oral communities in the context of this article can be seen by a name, a face and a particular identity, namely, indigenous people. This article will engage the work of Finnegan on what is 'Orality - if anything'. The term 'orality', as a conceptual tool, can help us to widen our horizons and attention to forms of human creativity and imagination which was neglected or unnoticed by scholars. Orality has forced scholars to ask new questions on what is the meaning of 'text' and encouraged and challenge scholars in orality and literacy research with a new analysis of what we thought we already knew. The article engages oral and written research and how it can assist in understanding the discourse of the 'Other' and the power relation in reconstructing and re-ordering of their social universe through collective memory, songs, rituals, satire, drama and political protest which at large was perceived by the apartheid era and Western colonisers as savage, uncivilised and barbaric. The oral discourse of the 'Other' has become part of the power struggles politically and educationally in South Africa. Orality has further reshaped the Christian discourse in South Africa and Africa as the poor and oppressed find new power in a discourse of metaphysics of presence of the Gospel through preaching and bearing witness of their new encounter spiritually.

Keywords: Orality; Literacy; Otherness; Communication; Marginalisation; Memory; Resistance.

\section{Introduction and background}

The history of orality is deeply embedded in the archival memory of the 'Other'. Drawing on the works of Brown (1995) and the founding scholars of the theory of orality and literacy (Goody \& Watt 1968; Havelock 1963; Levi Strauss 1962; Lord 1960; McLuhan 1962; Ong 1982), I shall argue that orality and literacy present the basic differences in the ways of managing verbalisation and communication in primary oral communities as opposed to cultures that are deeply affected by the use of writing.

Derrida (1976) in Of Grammatology discusses the critique of writing in the work Plato's Phaedrus (/'fi:drəs; Greek: Фaĩopos, transliterate. Phaidros). Phaedrus is a dialogue between Plato's protagonist Socrates and Phaedrus in 370BC. This dialogue revolves around the art of rhetoric and how it should be practicsed and should dwell on subjects like metemphychosis (Greek tradition of reincarnation) and erotic love (Wikipedia 2019). According to Derrida, Plato can be seen as the 'inventor' of 'grammatology' and the theorist of handwriting or ecriture. Plato begins with a myth offered by Socrates at the end of Phaedrus dialogue. This is not a philosophical argument but rather a myth. According to the myth as recalled... the Egyptian god Theuth presents King Thamus his most recent invention of writing. Theuth called writing a 'remedy, "recipe," "drug,"

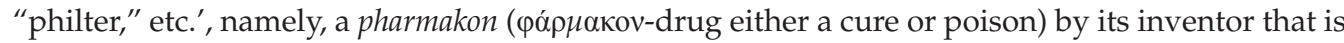
touted as a curative elixir or a remedy for forgetting. Writing as a pharmakon ( $\varphi$ óp $\mu \alpha \kappa o v-d r u g$ ) can either cure or poison the mind apposed to that of rhetoric. As King Thamus re-interpreted the myth, writing is not a remedy for memory, but rather a bane or poison for it because men (generically) will come to rely on it rather than the living memories. Socrates in his commentary on the myth condemns writing because it is cut off from living breath or self-present thought of its author. It is a dangerous pharmakon (фópнакоv-drug either a cure or poison) as it gives the 
impression or illusion of being knowledgeable in the absence of real knowledge. However, speech or logos stay close to that of living, breathe of the speaker (Naas 2010:46-47).

Baumann (1986) in his study on orality and literacy engages with Plato's and Socrates' criticism of writing. In the Seventh Letter of Phaedrus (pp. 274-277), Plato and Socrates point out four key arguments as opposed to writing: firstly, writing can be seen as inhuman; secondly, writing can be regarded as unresponsive; thirdly, writing can be seen as a thing (object); lastly, writing is further a technological product that weakens the memory of those who rely on it because writing cannot respond to new questions and it cannot defend itself (pp. 27-28). For Havelock (1963), in the Preface to Plato, Plato's the use of writing has turned him against Socrates oral tradition and the art of rhetoric (the art of effective or persuasive speaking or writing).

According to Brown (1995), orality and oral traditions amongst the 'Other' have existed for years throughout South Africa's oppressed history. For Scott in his book Domination and the Arts of Resistance (1992), Orality can be seen as dialogue between the public transcript (ideological hegemony) of 'Otherness' over against the hidden transcript (false consciousness) of the dominant class who have falsely constructed the histories of the poor and oppressed. Orality or oral literature is largely absent from accounts of literary history of the 'Other' in South Africa. The oppression of black people (e.g. mixed race and Indian descent) has contributed to the exclusion of oral forms of communication because of the interface of residual orality (writing and orality) as a result of the Group Areas Act of 1950. The act assigned to different residential and urban areas in a system of urban apartheid. The following system will allow indigenous languages to orally to development. Primary orality was largely associated with African communities as a form of communication through rituals, singing, dancing, poetry because of the marginalisation of writing by their colonial masters and slave drivers. The suppression of oral utterances of the 'Other' in favour of the printed or written text of the dominant class is a feature of literary studies worldwide and appears to be related to the critical practices that have been dominant in universities and schools for most of this century (Brown 1995:1-5).

For the purpose of this article, the contextual sample was drawn on South Africa's sociopolitical situation prior to 1994 from the perspective of orality and literacy. The South African history of racial oppression was legislated and inscribed by law (le Jure) through the power of writing in order to create a binary opposition between black people and their colonial masters. This binary opposition further extends to white and black people, literate and illiterate, which shaped social boundaries of racial segregation in South Africa. This article critically assesses the binary opposition between speech and writing and the social effects of the written text in South Africa prior to 1994 and the political history after 1994 or post-Apartheid period. A country where the power of the written text was a source of empowerment and economic welfare for the dominant class. This resulted in the disempowerment of black people for more than 40 years of illiteracy, economic exclusion and abject poverty. The only source of hope they had for survival was the bible and the spoken Word Logos (Jn 1:1) to strengthen them spiritually against oppression and poverty. The Logos [Word of God] that was given as a 'remedy, "recipe," "drug," "philtre," etc.' namely

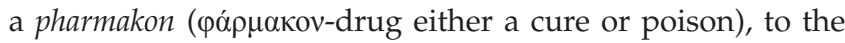
poor and oppressed to conscientise them in their oppression has became the hope of liberation and resistance of the historically excluded 'Other' against the forces of Apartheid and its corrupt policies. The Christ of Galilee was on the side of the poor and oppressed. This call for a hermeneutic from below. A new interpretive interest of the oral text, a text read from below which echoes the voices from the margins.

This seems paradoxical, but the poor and oppressed had no economic and political power but to re-enact the spiritual power of the Word, which became a mechanism of survival and resistance against the vile and evil operations and deeds of the dominant class and white superior nationalism. Twentyseven years later, the effects of such disempowerment can be seen in all spheres of South Africa's historically disadvantage communities, from higher education to schooling system, civil society, NGOs and corporate institutions, as black people are faced with challenges of academic literacies as well as the newfound media of communication, like computers, smartphones, digital satellite television (DSTV) and an array of different technologies. A move from oralate communities to traditional civil communities posed its own challenges in terms what is traditional and what is normative. Orality and literacy serve as a method to engage the binaries between orality and literacy and the discourse of the 'Other'.

\section{South Africa's literacy since the 17 th century}

When we talk about literacy in South Africa we have to keep in mind that although literacy was introduced in the 17th century by the European missionaries, the conversion of African languages into standard our literary languages was a joint project between the indigenous people of the land and the dominant class. This was highly dependent on African informants and experts. (Kruger 1992:225)

The introduction of both script and scripture through missionaries was so strongly connected that mixed-race and black communities in the Cape regarded the progress of the mission as the 'progress of the word'. This view was supported by the fact that, nearly exclusively, the missions had been responsible for black people and mixed-race education. They were in charge of a vast majority of black schools and institutions for higher education from the 18th century until the 1950s. Kruger (1992 ) states:

Attending a school was not the only way to get access to the literate world. African chiefs who were unable to read and write used missionaries as secretaries and sent their dependents to school. Sometimes, the African chiefs even employed literate secretaries especially to control European correspondence. From the beginning, literacy was not a white domain only. Moreover, to 
be white did not mean to be literate. Until the late 1920s, illiteracy was a serious problem among the white population in South Africa. About $35 \%$ of the white children had never seen a school in their life. At the same time, the Cape was looking at a history of 200 years of coloured education by Dutch and British and French missionaries. (pp. 225-254)

Meer and Zulu (1989) quoted by Narismula (1998) state that:

South Africa became a 'republic' in 1961 where the majority of indigenous people had a few basic economic, social and political rights. South Africa remained an oppressive society, where the white minority maintained political and economic control. Black people continued to remain powerless, with no access to economic and social power. In the late 1960s the culture of resistance, that the state had tried to decimate earlier in the decade, began to regenerate. The resistance took the form of local organisations, which advanced the struggle of the political organisations that had been banned. In addition to challenging the existing social order, the resistance organisations tried to reconstruct South Africa society. (p. 1)

The following argument by Narismula (1998) maps the political context of orality as resistance against the false conscious construction of reality by the dominant class:

In a highly politicised society, many black artist and poets would not allow themselves to be alienated from the key political struggle. Orality and resistance literature was not just seen as the expression of individuals or small groups but of an entire social movement to end oppression. Oral composers resisted the repression and the censorship of the state and the prescriptions of the conservative-liberal critics. Literary and oral activists and poets developed tactics to deal with the silencing of the poor or the 'Other'. (p. 1)

The core reference of the term 'Other' has been to that sector of the population most oppressed by the apartheid regime, who had been named and misnamed during the apartheid history and who had been referred to as 'black' in the social sciences. Owing to the hegemonic forces of colonialism, apartheid and neo-colonialism, the construct of the 'Other' has not functioned as a marker of inclusive belonging and identity, as occasioned by the index of geography or social boundaries. Instead, the term has signalled the other of apartheid, consigned to geographic, social and psychological distance, as well as to deprivation and underdevelopment. As with all oppressed groups, the abjection and enforced silence of the 'Other' or those that are traditionally from the non-European background is evident in the inappropriate names that have been imposed on the 'Other' (Miller 1990:35).

By constituting and ranking 'racial groups' in a self-serving hierarchy, the dominant minority established exclusive boundaries and secured enormous power. The term 'black' has stood as the binary opposite of 'white' and signified its 'otherness', at least historically. Like other oppressed groups across the world, black people responded by embracing the designation 'black' and using it as a cornerstone of their attempts to reconstruct their identity. The regime's secondranking construct of 'mixed race', into which any other person could fit, shows up the fictiveness of its racial classification.
While in the broader sense the term 'black' affirms the unity of all oppressed South Africans, it can mask the fact that while black people as a whole were systematically marginalised and subjugated in social, economic, political and cultural terms, the apartheid oppression was not uniform among the different racial groups. Racial minorities, such as mixed race and Indians, were given more rights than African people, while the African majority were subjected to the most serious atrocities of the apartheid regime.

\section{According to Fanon, quoted by Alessandrini (1999):}

[T]ell us about the relationship between decolonised, the future and the colonial present ... "where the colonial order had rendered "oral traditions" "inert" and reduced pre-colonial cultural forms to a state of petrification, these new practices operate in accordance with, and offer to redeem, the vibrant and communitarian cultural practices of the pre-colonial era. (p. 171)

$[T]$ he oral tradition - stories, epics, and songs of the people which for merely were filed away as set pieces are now beginning to change. The storytellers who used to relate inert episodes now bring them alive and introduce them modifications which are increasingly fundamental. There is a tendency to bring conflict up to date and modernise the kinds of struggle, which the stories evoke, together with the names of heroes and the types of weapons. The method of allusion is more and more widely used. The contact of the people with the new movement gives rise to a new rhythm of life and to forgotten muscular tensions and develops the imagination. Every time the storyteller relates a fresh episode to his public, he presides over a real invocation. The existence of a new type of man is revealed to the public. The present is no longer turned in upon itself but spread out for all to see. The storyteller once more gives free rein to his imagination. (p. 171)

Orality was regarded as a major tool of resistance that had been used by primary oral cultures in South African order to oppose the colonial oppressive regime and its oppressive practices. This can be seen in the way the storyteller conscientises his or her audience and then reverberates this allusion through storytelling which enkindles a new hope that gives rise to a new rhythm of life in the midst of their struggle for liberation from oppression. Orality throughout post-colonial South Africa will continue to survive because of its primordial and transcendental essence of the spoken word that creates and shapes the new social construction of reality for the poor and oppressed.

It was against the background of these socioeconomic events that 'orality' or the power of speech became a mechanism of resistance for primary oral communities. The voices of the oppressed echoed liberation and resistance through verbal arts, gestes, poetry, extemporaneous prayers and preaching, spiritual hymns and freedom songs in opposition to the ideology or false consciousness of their oppressors. For the oppressed, the power from below is rooted in the spoken authority of the Word and the Spirit. Transcendence or metaphysics of presence becomes a new form of power for the poor and oppressed over against the vile atrocities and false conscious ideology of the dominant class. 
Finnegan's (1990) thesis on Orality if anything refers to critical engagement in the discourse of the 'Other' or 'subjugated poor and oppressed'. Orality or the power of speech of the 'Other' has become a mechanism of resistance over against oppression. It can be seen as a way to reorder the social reality of the dominant class or the oppressor through words, satire or gestes. In the face of the public transcript, the literal abuse of black beingness, identity, selfhood and racism denounces whiteness and its superiority in being subservient to their slave masters in the public domain, whereas the hidden transcript manifests the oral imaginative power of the poor and oppressed that is deeply rooted in transcendence and metaphysics of presence against the dominant ideological practices and their abusive colonial masters. Voices of resistance echoed through the social and political history of South Africa as verbal arts and gestes, poetry, spiritual hymns, freedom songs and extemporaneous preaching opposed and denounced the policies of the previous apartheid regime - calling it inhumane and evil. This discourse continues to play itself out in a post-apartheid era in using orality to conscientise the poor and oppressed with political jargon to opposing forces of oppression whether it is economic or political.

Finnegan (1990) asked the question, what is orality - if anything? She concludes her thesis 'that orality it is nothing more than an academic slogan'. Finnegan provides a critical assessment on orality from the perspective of anthropology, literature and poetry. She highlights key concerns on orality. For her, orality, together with its adjectival 'oral', is a term that can be found widely in classic scholarly writings. From Homeric text to an arrange academic disciplines in a different interdisciplinary context, for example, folklorist, anthropology, biblical studies, linguistic and semantic studies. Finnegan asks, what exactly is 'orality'? According to her orality and literacy studies widen scholar's perceptions of the work of human and literary imagination as well as open new doors into the appreciation and interpretation of human culture by scholars in the use of the term 'orality' (1990:131-147).

\section{Orality and literacy as a method}

The word 'orality and literacy' in relation to the methodology of this article is probably one of the dirtiest words in the indigenous world's vocabulary when mentioned in many primary oral cultural contexts, as it stirs up the silence, it conjures up bad memories and it raises a smile that is knowing and distrustful. It is so powerful that primary oral people write (not in the written text but through oral text gestes, verbal arts, poetry, hymns) about Western scientific research. The ways in which scientific research or empirical research is implicated in the worst excesses of European colonialism and imperialism remain a powerful remembered history for many of the world's colonised people (Smith 1999:2). This has been evidently seen in Africa, India, South Africa and globally - how European and Dutch colonialism used policies in South Africa to take full control over African societies as they exploit them economically. These memories daily live with the 'Other' as they cry at times of the pain of losing everything at the hands of the colonisers.

This article attempts to identify research as a significant struggle between the interest and knowledge of the West of primary oral cultures and the interest and ways of resisting of the 'Other'. In this example, the 'Other' has been constituted with a name, a face and a particular identity, namely, indigenous people (Smith 1999:1). Boehmer (1995), a postcolonial theorist refers to the colonised as the colonial 'Other'.This concept of the 'Other' is built on the thought of, inter alia, Hegel and Sartre that signifies that which is unfamiliar to the dominant subjectivity or which is against the control, intimidation and hegemonic authority of the dominant class (Boehmer 1995:21-26).

While it is more typical to write about research within the framing of a specific scientific disciplinary approach, it is difficult to discuss research methodology and indigenous or primary oral cultures together, in the same breath, without having an analysis of Western imperialism and colonial sophistry, without understanding the complex ways in which the pursuit of knowledge is deeply embedded in the multiple layers of colonial and imperial practices (Smith 1999:2-3).

In search of a method I have looked at the work of several oral theorists, namely, Havelock (1963, 1986), Foley (1994), Ong (1982, 1987, 1995), Tannen (1982), Finnegan $(1988,1990)$ and Graham (1987), to substantiate my critical analysis about orality and the binary opposition between the oral and written text and its relation to primary oral cultures. Most these oral theorist namely, Havelock (1963, 1986), Foley (1994), Ong (1982, 1987, 1995), Tannen (1982), Finnegan (1988, $1990)$ perception of orality is rooted in a Western paradigm of text-centrism or residual orality (the interface between oral and literate) rather than primary orality or oral text of the 'Other'.

With the dominance of textuality of the West, there is a need to review the hypothesis of the spoken authority or orality in relation to the 'subjugated Other'. Ong (1982) hints at the remarkable difference between primary and secondary oral cultures. Primary oral cultures operate with the spoken word ( $\lambda$ ó $\gamma \circ \varsigma, o v, \dot{o})$ or word in space, whereas writing is not central in these communities. Primary oral cultures have no significant form of written communication other than the oral 'text'. Can one speak of literature in the case of oral 'text'? This can be seen as a paradox in relation to primary oral cultures because in primary oral cultures memory serves as a means for storing information, whereas in literate communities the written text is a fixed artefact and serves as a substitute to support a loss of memory as explained by Plato and Socrates (Finnegan 1990:138-141). Secondary or residual orality refers to cultures that are literate communities or cultures that construct their reality chirographically or through writing. This is very different for oral communities as their social universe is constructed through the spoken 
word and provides a unique sense of interpretive interest in these communities.

Primary oral cultures across the world have other stories to tell, for example, the history of Western research through the eyes of colonised people (Smith 1999:2). These counter-stories are powerful forms of resistance, which are repeated and shared across diverse indigenous communities. Primary oral cultures do not differentiate between scientific research and that of verbal arts and gestes.

For the 'Other' there is no dichotomy in relating to the world. Their worldview is holistic and real with no dichotomy between spirit and existential reality as the world below and above gives meaning and interpretation to the oral text for the poor and oppressed in the midst of their struggles, pain and challenges. Their hymns, song, poetry, toi-toi, prayers (resistance dance) all echoed resistance against the powers to be and their written policies which imprison and shape the social construction of reality of the 'Other' by their colonial masters. A God that side with the poor and oppressed. The written text creates binary oppression between literate and illiterate, rich and poor, powerful and powerless, white people and black people. We can go on and on in affirming these binary oppositions, but there is a need to methodologically place it in perspective of this article.

The perspective of 'orality and literacy' helps to understand the social dynamics of the discourse of the poor and the oppressed. The written text was seen as a construction of the dominant class or the privilege over against that of the historical 'Other'. This resulted in the social exclusion of oral communities from the social construction of the written text which only highlighted the superior history, triumphs, civil identities, superior language construction and colonised DNA (superior race group) of their colonial masters. The histories of the 'Other' (including mixed race and Indians) was distorted through lies or sophistry of different race groups, misfit identities, cultural misrepresentation, name changing of the 'Other', and racial classification and boundary restrictions for the poor and oppressed. The only way these cultures survive the oppression by their colonial masters was holding on to the spoken authority of the Logos in their cultures as churches used residual orality through preaching, prayers, singing and spiritual dancing denouncing the oppressed policies of the apartheid government. This was their way of spiritually and socially connecting as communities of faith over against the bureaucratic construction of writing, which creates boundaries, segregates the 'Other' and creates double consciousness of black identities and helps to displace their cultural archives and memories.

According to Ong (1987), 'Orality and Literacy research' as cross-cultural studies enrich the human spirit and open a greater understanding and love between diverse people. The 'more authentic human beings are, the more there is in them the ability to be free from the illness of segregation and racial
boundaries'(Ong 1987:181). Orality interpretive interest opens new insights into the understanding of the histories and cultures of the historical 'Other'. Beneath the socially constructed 'Otherness' lies a vast oral tradition (rituals, language and cultural archives) which has been covered under a myriad of falsely constructed writings of the West and their colonisers.

\section{Orality the language of subjugated 'Other'}

Ong (1982) provides a fascinating account of the understanding of oral and literate communication. Spoken and written words are two different linguistic media for communication. Although this is not generally accepted by oral theorists like Finnegan $(1988,1990)$ and Tannen (1982), yet according to Ong (1982):

A deeper understanding of pristine or primary orality enables us better to understand the new world of writing, what it truly is, and what functionally literate human beings really are: beings whose thought processes do not grow out of simply natural powers but out of these powers as structured, directly or indirectly, by the technology of writing. Without writing, the literate mind would not and could not think as it does, not only when engaged in writing but normally even when it is composing its thoughts in oral form. More than any other single invention, writing has transformed human consciousness. (p. 78)

Orality discloses new ways and hermeneutical benefits in relation to the meaning and representation of the text and the interpretation of the 'Other'. In this example, the 'Other' has been constituted with a name, a face and a particular identity, namely, indigenous people.

This has helped us to broaden our perceptions of the works of human literary imagination (Finnegan 1990:130). Orality has helped us to appreciate human culture, especially from the other side of history with narratives of different kinds, poems and traditional songs. The term 'oral' is preferable also to 'illiterate'. Illiterate refers to persons in a literate culture who have not to learn to read and write. 'Illiterate' is a term that marginalises people in a literate society (Ong 1987:174).

The term 'orality' gives a kind of validity to the non-written material. Its aim is to understand primal human cultures. This has helped us to turn our attention to the voiceless, the poor and oppressed that were often unheard and marginalised by oppression in communities. The 'oral texts' have been subjugated under the written text. The oral text can be seen as oral art that reflects the struggles in memory of marginalised communities, in the form of political protest songs and satires (Scott 1990:246).

For Finnegan, the oral directs our attention to certain features of unwritten literary expression that was not obvious to scholars. The concept of orality has also challenged scholars to turn to new questions and to revive interest in certain issues. The appreciation of the oral quality of certain forms has also 
led to new theoretical approaches and questions in the sense of rethinking of some older problems and a new look at some of the existing text, whereas oral theory and oral provide extra impetus and confidence (Finnegan 1990:131-136).

Orality raises new interest and questions about the meaning of 'text', particularly what is a 'text' and how should we interpret the oral or written text. For many such questions seemed unnecessary, but the recognition of the oral text is both dynamic and ephemeral. The character of the 'oral text' follows the need to think about the processes by which such text becomes written and by whom they are automatically fixed and completed forever. Such questions raise concerns about the Western model of 'text' which can be seen as bounded and final. A kind of enduring abstract model divorces from contingencies and context or performance of an oral text that play itself out in a local community of the 'Other' (Finnegan 1990:137-138).

In Latin, the word (textus) is referring to the word as weaving. According to the online etymological dictionary, text in the 14th century refers to 'wording of anything that is written', from the Old French text to Old North French text refer to text, a Book or the Gospels. In the 12th century, from the Medieval Latin text refers to Scripture, text, treatise. In the Latin, 'text' refers to written account, content, characters used in a document. From the Latin, textus means style or texture of a word, literally things are woven together [Robert Bringhurst, 'The Elements of Typographic Style' 1992]. According to an ancient metaphor:

[T] he thought is a thread, and the raconteur is a spinner of yarns but the true storyteller, the poet, is a weaver. The scribes made this old and audible abstraction into a new and visible fact. After long practice, their work took on such an even, flexible texture that they called the written page textus, which means cloth [Robert Bringhurst, 'The Elements of Typographic Style' 1992].

The metaphor is obvious, you tell a story as a weaving of words as a piece of cloth. The repetition and pattern of storytelling, is moving the story along a path like a piece of thread you are spinning, putting large pieces together, crafting small pieces carefully, to get the story or genre together. A story or lend is passed down orally from one generation to the next generation which later becomes part of a community tradition. The art and craft of storytelling remain valuable for the primary oral community. This is especially in a non-literate community or primary oral communities weaving the 'oral text' through stories, folklore, Anansi (trickster culture), myths and gossip.

For Schipper (1989) observes that oral 'text' does not exist without the performance itself: the very presence of the performer, storyteller, singer, without whom oral literature cannot exist which is a fundamental characteristic which in the past has often been overlooked. Oral interpretation of literature has often been left to scholars of literature and as a stepchild to anthropologist, folklorists who lack in the hermeneutical understanding of the word 'text' (1989:66).
Oral 'text' needs to be understood as the body serves as a social system of communication of the subjugated "other", and this includes the oral and aural phenomena of the oral word.

For Ong, the condition of words in a text is different from their condition in spoken discourse. The word in its natural, oral form is part of a real, existential context where both the hearer and the speaker create the meaning of the text (Ong 1982:101). For oral communities, there is no fixed human art or workmanship. The spoken authority of the word shapes the oral transmission processes, which create meaning and representation between the speaker and the hearer. The spoken utterance is addressed to a real, living person at a specific time in a real setting. For Ong, we have been addicted to thinking unreflectively of oral utterance not by examining primary oral cultures utterance as such, but by understanding them with written text (Ong 1995:9). Tannen (1982:3) observes that oral cultures reflect formulaic expressions (such as sayings, cliches and/or proverbs). In oral cultures, the meaning is not contained in words themselves, but words share a social meaning in the context of the community in contrast to literate traditions where the meaning is in the text (Tannen 1982:3) and has been fixed on the ephemeral rather than on the physical.

Orality has been fixed on the ephemeral instead of on the physical. Walter Ong notices that "when all verbal communication must be by direct word of mouth, ... interpersonal relations are kept high-both attractions and, even more, antagonisms"(1982:45). For Ong oral cultures sound very agonistic in their verbal performances. Waugh (1995) further argues that:

$[W]$ hen all verbal communication must be by direct word of mouth, ... interpersonal relations are kept high - both ... 'reciprocal name-calling' sessions are 'standard in oral societies across the world'. (p. 44)

If one looks at the anatomy of orality, one finds that the word connects with the body directly. There are five types of bodily communication:

- Expressing emotions: mainly by face, body and voice.

- Communicative interpersonal attitude: we establish and maintain friendship and other relationships mainly by non-verbal signals, such as proximity, the tone of voice, touch, gaze and facial expression.

- Accompanying and supporting speech: speakers and listeners engage in a complex sequence of glances, non-verbal vocalisations that are closely synchronised with speech and play an essential part in the conversation.

- Rituals: non-verbal signs play a prominent role in greeting and other rituals.

- Self-presentation: it is mainly achieved by appearance and to a lesser extent by voice (Argyle 1988:4-5).

In this dichotomy between oral and written, it can be concluded that 'speech is a cosmic and invisible architecture 
of the human dark, whereas writing was the visualisation of the acoustic space' (McLuhan 2005:66). Spoken words are more emotional than written words. It is not only oral in form but also a combination of the human sensory (mouth, ear and eye). The body becomes a social system of communication, and we tend to react to each situation that occurs, even to our own act of speaking, whereas writing can rather be seen as a more specialist action in which there is little opportunity or call for a reaction like the spoken word (McLuhan 1967). The spoken word carries emotion as well as meaning in real time, which creates meaning and representation of the 'oral text' for oral communities.

Orality always bears a human face and always has a human body. Any transmittance of human knowledge has physicality because the memory cannot recall information without the voice that speaks it. Knowledge, once acquired, had to constantly reverberate or it would be lost (Ong 1982:24). The oral poet thinks of speech as breath or ruach-inin [wind or spirit]', a possession that others can steal and take it ceaselessly. One can even steal from one's own speech and compositions. As the Old English suggests, 'since speech is stolen from language, it is thus stolen from itself' (Waugh 1995:364).

Orality in view of Finnegan (1990), Graham (1987) and Ong (1982) can be seen as an abstract and unclear in its definition. For Finnegan, orality is nothing but rather a fashionable term and another academic slogan. However, for Graham and Ong, orality reflects the subjugated culture or tradition of the poor and marginalised through their poems, hymns, stories, folklore and indigenous knowledge. These oral transmissions always operate with hidden assumptions or subversive hidden engagements. This may not have fully satisfied our question about the meaning of orality, but it opens new ways, reflecting on the power of the spoken words that have been exiled in the written text. Underneath the textuality, which seemingly imprisoned the spoken words, lies a network of oral processes, and a community that has shaped the production processes and transmissions of the written text. The Western understanding of orality has been perceived chirographic construction (or words in written forms) or as residual orality. Residual orality refers remnants and legacy and influence of oral cultures with written forms - an orality that is self-constructed and totally removed from the real context of primary oral communities. The 'Other' perceived their world through the power of words and socially re-order their universe, communities and families through songs, hymns, poetry, storytelling, speeches and folklore.

In returning to our initial question: what is Orality - if anything?, Finnegan argues that in one sense Orality is not anything but it is rather a fashionable term and one which, as I have indicated, carries a whole series of hidden assumptions. There is also something in this term "which appeals to the romantic and mystical in us, that calls from the far-away but treasured 'other', the nostalgic 'world we have lost', a powerful and in it way valuable appeal' (Finnegan 1990:146).

\section{Oral and literate societies}

Jack Goody (1977) has convincingly shown how shifts hitherto labelled as shifts from magic to science, or from the so-called 'prelogical' to the more and more 'rational' state of consciousness, or from Lévi-Strauss's 'savage' mind to domesticated thought, can be more economically and cogently explained as shifts from orality to various stages of literacy. I had earlier suggested $(1967 b, 189)$ that many of the contrasts often made between 'western' and other views seem reducible to contrasts between deeply interiorized literacy and more or less residually oral states of consciousness. (Quoted by Ong 1982:29-31 from the work of Goody)

The above citation captures the basis of the adoption of Orality in the literacy discourses. In the early 1960s, several books were written on oral and literate cultures. These included The Savage Mind by Lévi-Strauss $(1962,1974)$, the French anthropologist; The Preface to Plato by Eric Havelock (1963) and several articles by Jack Goody (1968, 1977). Werner Kelber's (1994) article "Jesus and Tradition: Words in Time, Words in Space." In Orality and Textuality in Early Christian Literature, argues, 'that such a powerful thesis was needed to break ground, to fracture the wellestablished sinecure of textual or chirographic thinking that reflectively dominated earlier scholarship' (cited in Foley 1994:150). These works and many others brought to prominence what came to be called 'orality and literacy' research. Orality and literacy binary opposition represents a new field of study and has made critical input in psycholinguistics, sociolinguistics, anthropology, history, New Age Criticism, reader-response criticism, religious history and theology (Christian, Jewish, Islam and other comparative religions).

According to Ong, orality and literacy are beginning to revise the history of the West, as they reveal the oral-agonistic nature of the different schools of thought which until recently were populated exclusively by white males who taught in chirographic (written) controlled but orally targeted languages (Ong 1987:172). A classic example of this was the white missionaries who were sent to Africa to learn the language of the indigenous African communities and to colonise them with a hidden agenda of the West. For them, all things European were superior to that of the African culture, which was seen as uncivilised and barbaric.

Those theorists involved in the comparative modes of communication frequently refer to a binary divide between different kinds of societies or human experience, for example, 'Primitive versus civilised', 'simple versus advanced' and 'preliterate versus literate'. This binary account has been referred to as the 'Great Divide' or Western (First World) over Third World school of thoughts. Such theories suggest radical, deep and basic differences between modes of thinking in literate and non-literate societies (Ong 1987:173). Ong quotes Johannes Fabian, as he reported on the ways in which Western anthropologists have in the past collected data of primary oral communities whether unconsciously and subtly, downgraded 
oral peoples who have been the subjects of their research (Ong 1987:173). Data collected about primary oral communities were ideologically driven, biased and questionable in terms of its social scientific content. This was pure Western sophistry.

Goody (1968) denies any significant distinction between literate and non-literate societies as he adopts a widely criticised stance of cultural relativity. He argues that 'general' rather than radical differences exist between non-literate and literate (Goody 1968:67). Goody advanced on the work of Levi Strauss's 'Great Divide theory' as he sheds light on the changes that were brought about by writing. The difference between purely oral communication and communication based on the printed word is that the oral word is ephemeral, whereas writing remains a fixed artefact. What makes the scientific mind scientific is that it has the tool of writing at its disposal.

According to Goody (1977), human communication is the basis for social institutions and normative behaviour. The changes and modes of communication have implications in primary oral cultures. In focusing on the medium of communication, Goody echoes the well-known dictum 'the medium is the message', with its focus on the form of communication as in the written text (Goody 1977:9). Writing has become the new-found communication to connect ideas and seen 'truth' whereby speech has been downgraded to primary oral communities as a medium of communication.

Goody thus reiterated that the written word construction does not replace speech any more than speech replaces gesture. Within a politico-legal domain, the growth of bureaucracy clearly depended on the ability to control the 'other' relationship by means of the writing. Cooley quoted by Goody defines primary oral groups closely to pre-literate societies, that is, those characterised by intimate face-to-face association (Goody 1977:15-38). For Goody, face-to-face groups have no need for writing because the relationship between 'others' is largely oral and often non-verbal.

Western culture has assigned unusual importance to the written text, especially the printed word. The written text has enjoyed a special status in every literate society. The replacement of purely oral transmission by the use of the written word has been a repeated pattern of historical development across all geographical and cultural boundaries. There is something about the written word that bespeaks of authority and reliability in its very namelessness and independence of particular and individual memories (Graham 1987:59). Writing as a fixed text has contributed to this authority from the time of its discovery and was further sustained by an elitist white male academic community, which perceived the written text as autonomous. Writing, it is true, marks a dividing line between the oral and the literate. It is technology that restructures thought and consciousness. As such it is one of the most pervasive and radical tools over the centuries and across the surface of the world (Ong 1987:174).
For Barthes language is not only an instrument of speech but also a dialectic process. Barthes in a short essay on 'The death of the $[A]$ uthor', rejects the traditional view that the author is the origin of the text. The $[A]$ uthor is not simply a person but a socially and historically constituted subject. For Barthes, the $[A]$ uthor does not exist prior or outside the construction of language. Barthes shifts the emphasis away from an allknowing, unified, intending subject (Selden 1985:75). According to Barthes (1972), there is a need to liberate writing from the despotism of what he calls 'the work', or 'The Book' or the 'End of the Printed Book':

To give a text an $[A]$ uthor is to impose a limit on that text, to furnish it with a final signified, To close the writing (...). However by refusing to assign a 'secret,' an ultimate meaning to the text (and the world of the text), liberates what may be called an antitheological activity, an activity that is truly revolutionary since to refuse a fix meaning is, in the end, to refuse Gos and his hypotases, reason, science and law. (p. 112)

Barthes' formula is radical in the dismissal of such humanistic notions, where the author is stripped from his or her metaphysical status and reduced to a location of infinite citations, repetitions and references. This shows that the literary work is independent of historical and biographical background. The opportunity and ability for each of the readers to add, alter or simply edit the text opens possibilities of collective authorship that breaks down the idea of writing as originating from a single source.

Primary oral cultures are societies that did not have writing to facilitate their day-to-day communications. There was a world of direct verbal communication, the simultaneous and immediate presence of the speaker and his audience. This makes up the very essence of communication. This auraloral communication was characterised by the transmission of tradition by means of a range of mnemonic faculties and mnemotechnical devices, which were deeply rooted in human language. They have great wisdom, but none of them has the extended analytic explanation of the world, what we call science today, which not only includes the physical sciences but also the human sciences, such as the study of verbal utterances, written and oral (Ong 1987:178).

In primary oral cultures, mimic and gestures, together with memory, play a crucial role in affirming their traditions, customs, values, and ways and life which are ingrained through regular practice in daily activities, for example, religious festivals, ceremonies and rituals (initiation rites) stored in the memories of people and passed on from generation to generation. This memory serves as an archive for stored information. Oral discourse builds up and repeats; it reinforces the same themes. Simply put, both the form and function of oral discourse maintain tradition by telling coherent, organised stories (Rubin 1995:15).

Written or chirographic cultures (cultures with writing) tend to think of words as labels for the thing they describe. 
Writing leads to visual metaphors: perspective, focus, trace or point of view. Writings, with their reliance on vision, lead to an emphasis on things instead of events and processes (Ong 1982:31). In a literate culture, the archives are libraries of printed text, which are contained in the stored information. This information can be referenced, assessed objectively and reflected upon long after it is written. In an oral society, this cannot be done as one cannot look up for any information, for speech is ephemeral because it dies the moment it is uttered unless it is stored in someone's memory. For Jousse (1997), memory is instrumental in constituting the 'oral archive':
... [T] he capability to re-play a perceived reality in its absence, to represent something past is unique to man and it is a memory that allows him to do so and thus makes man unique through memory, he replays experienced reality stored in him, through memory he conserves and transmits consciously his past actions and reactions and so are enabled to shape his future according to the experience of the past. (p. 167)

According to Rutkus (2014) in order for culture to survive, its traditions must be transmitted orally and through time. How could they communicate with future generations? The speech could not be used because it is an acoustically based phenomenon, and sound exists only ephemerally, but the human mind could store the knowledge it received through hearing and understanding speech.

Thus, a density of memory was created as information and the human experience was compressed and amplified. New information had to be edited for brevity and fit to conform with old knowledge in order to be remembered. (Rutkus 2014)

For Havelock, the mind serves as a storage container, and memory assumed a central role in cultural survival (1986:55). Jousse (1997) says:
Memory! We no longer have any idea of its capabilities! When simply strung together like beads the series of texts that make up this work on rhythmic and mnemonic oral style, the philologist cried out: 'But it is absolutely impossible that human memory should have such powers!' This is because they themselves were being totally devoid of memory, almost never having exercised it. This is how reactions to some fact that have been put into new relief can be dictated by a person's training. We judge on the basis, of what we are. (pp. $x x-x x i)$

In oral societies, a premium is put on memory, on recollection. Oral societies develop sophisticated mnemonic devices to help them remember. A respected member of a community, called a 'bard, priest, prophet or seer', held the role of cultural communicators (Havelock 1986). These speakers could recite from memory stories, poems, hymns that last for hours, and some only needed to hear a long story or a song once to commit it to memory (Havelock 1986:77). According to Smith:

This collective memory of Western imperialism has been perpetuated through the ways in which knowledge about indigenous peoples was collected, 'classified and then represented in various ways back to the West, and then, through the eyes of the West, back to those who have been colonised. (1992:1-2)

Edward Said quoted by Smith (1992) refers to this process as a Western discourse about the 'Other' which is supported by colonial higher education institutions, colonial vocabulary, scholarship, imagery (bewitchment of imperial language) doctrines, even colonial bureaucracies and colonial styles. This process has worked partly because of the constant interchange between scholarly and the imaginative (false consciousness or sophistry) construction of ideas about primary oral communities (Smith 1999:2). The whole idea of the 'Other' is linguistically and ideologically constituted by the West and can be seen as a social construct, which is in desperate need of deconstruction and decoloniality.

Repetition is a vital method of fixing ideas in the mind. As Walter Ong writes, 'oral societies must invest great energy in saying over and over again what has been learned arduously over the ages' (Ong 1982:41). His ideas became fixed in the mind of the bard, poet or priest, and he repeated them in the minds of the community. Repetition or redundancy also assured audience comprehension. In acoustically demanding situations, 'such as outdoors or in a room with or without sound-conducting' qualities, each word may not have been heard by each listener. Giving the audience more than one opportunity to hear important phrases, therefore, aided the spread of cultural knowledge (Ong 1982:40).

Primary oral society is one that does not have scientific skills for presenting communication in written form. There is instead a heavy reliance on memory and the traditions of such societies are kept alive by various institutions (e.g. churches, synagogues and community leaders): beliefs, practices and ceremonies (e.g. Eucharist, marriage, initiation rites and funerals), which form an intricate part of the life of the oral people, but deeply textualised culture study of oral performance will always bear some marks of textualised habits of their investigators, although intelligence and the mind are reflective, and can turn back on itself.

\section{Attributes of oral versus literate}

Ong and Havelock each look at some of the characteristics that oral cultures typically display. According to Havelock (1986), 'a general theory' of orality must build on a general theory of society. It requires understanding communication as a social phenomenon, not as a private transaction between individuals. The language of any kind acquires meaning for the individual only as a community shares that meaning, even though the individual is not addressing the community (Havelock 1986:68). Orality must always be seen in relation to a community rather than to an individual.

Primary oral cultures have no means of communication other than signage, which refers to the design or use of signs and symbols to communicate a message to a specific group or 
culture. Havelock notes that 'in primary orality, relationships between human beings are governed exclusively by acoustics (supplement by visual perception of bodily behaviour)' (Havelock 1986:65). This idea led Ong to his understanding that 'orality is "evanescent" rather than permanent' (Ong 1982:32) because sound disappears immediately after it is made, speech is inherently temporary. In oral cultures that have no means of recording except in memory, once something has been spoken, it cannot be retrieved. This causes oral cultures to view words as having some sort of magical power (1982:32). After the reverberations of the uttered sound cease, nothing remains apart from the memory of the sound and the meaning is conveyed.

Primary oral cultures could store and retrieve knowledge with only the ephemeral sound of the human voice. The sound has a special relationship to time: sound exists only when it is going out of existence. There is no way to 'stop' or 'have' sound. This leads to the perception that words are events, and as a result, oral cultures tend to give words greater power. The concept Logos as transcendence embodies the meaning of the word, power and spirit (Ong 1982:32). The sound has a special relationship to interiority, to the inside of things and people, in contrast to vision's connection to exteriority.

The evanescence of speech causes the evanescence of thought. Ong (1982) notes that:

In the total absence of writing, there is nothing outside the thinker, no text, to enable him or her to produce the same line of thought again or even to verify whether he or she has done so or not. (p. 34)

It is futile for members of primary oral cultures to spend their time thinking complex thoughts or coming up with complex solutions to problems unless they have a method of remembering their thoughts outside writing. According to Havelock (1986):

... [T] he answer would lie in ritualised utterance, a traditional language that somehow becomes formally repeatable like a ritual in which the words remain in a fixed order. Such language has to be memorised. There is no other way to guarantee its survival. (p. 70)

Primary oral speech tends to be formulaic, that is why poetry and rhythmic speech is non-literary. Ong (1982) explained in the work of Fowler (1994), how secondary orality of the electronic age can awaken us to the primary orality of antiquity ...

Writing, on the other hand, is a permanent record. Print seems unchanging and everlasting. Writing is open-ended and resists closure. With the intervention of the printing press during the time of the Reformation, notions of closure and completeness develop that are unthinkable in orality and difficult in the manuscript culture. (pp. 31-32)

Another attribute of primary oral speech is 'contextual versus abstract thinking'. According to Ong (1982:41-42), quoted in Fowler (1994), persons in oral cultures live in close, intimate connection with their environment and with each other. They tend not to think in distanced or abstract ways about the world and their lives. All thinking is concrete and operational. Learning is hands-on, by apprenticeship or discipleship. They conceptualise in terms of immediacy, in terms of their worldview, and spoken words are always in their own context (Fowler 1994). Speakers of an oral language rely more on the context for the communication of their message.

\section{For Greenfield (1972):}

Context-dependent speech is tied up with context-dependent on thought

Which in turn is the opposite of abstract thought? (p. 169)

In comparing the oral and written cultures, Greenfield (1972) says:

If the speaker of the oral language depends on the surrounding context to communicate his message, then effective communication presupposes a common context and common point of view for both listener and speaker. He [speaker] is, therefore, egocentric; that is, he takes for granted, without being aware of doing so, that his point of view and frame of reference are the only possible ones. At times, this assumption may be valid, at other times, not so. (p. 170)

In oral cultures, communication is invariably face to face or by word-of-mouth dialogue. Oral languages do not spread as far as the written language and are therefore shared by a smaller group. Fowler in the hypertext article 'From Orality to Literacy to Hypertext: Back to the Future?' elaborates and discusses from the work of Walter Ong (1982:42-43) on how Orality is close to that of the human lifeworld.

The practice of writing presupposes distance in time and space between author and reader. Writing lends itself to abstraction as it encourages the development of mental habits of distanciation and objectification. Whereas sound envelopes the bonds of speaker and hearer, writing marks the separation of author and hearer. (Fowler 2006)

Writing is context-free or an autonomous discourse that can be written in one social context and can be read in another (Ong 1982:78). However, in an oral culture, the elders are respected and appreciated for their indispensable memories to benefit from the acquired wisdom of one's culture. This is closely seen and observed in traditional African communities as oral communities' live close to the environment and nature. The African worldview is inclusive rather than that of Western dichotomy. For traditional oral communities, nothing is an abstraction but integrated and one.

Another trait of primary oral speech is it's 'agonistic versus fixed notions of truth'. Ong observes that primary oral cultures often evidence wars of words, such as a riddle or a song contest, name-calling or bragging. For them, communication is always a dialogue, as there are always at least two people present. There is no single, fixed text as in 
writing. This fosters the sense that truth is an ongoing process, one that comes from the conflict between views. Oral societies tend to see truth as an agonistic process (Ong 1982:45). On the contrary, writing separates us from each other. It fosters the sense that knowledge is static and that the knower is separated from the known. The structure of writing is monologic rather than dialogic (speaker and hearer are distanced in time and transactional space). According to Ong (1982), there is no way to refute a text, as after absolutely and total and devastating refutation it says exactly the same thing as before. The text is inherently contumacious (stubborn, disobedient) (Ong 1982:79).

Ong's next attribute of primary oral speech is that it is 'participatory rather than an objective'. In oral cultures, knowledge is produced through direct participation and an emotional connection. It comes from a connection either to the person passing on knowledge or to the concrete thing being studied. Writing separates the knower from the known. This leads directly to Western culture valuing objectivity over subjectivity (Ong 1982:46). In literate societies, knowledge is seen as something non-human, something we find or need to discover, not something we create in our interaction with each other. A classic example of this is found in the work of Plato, who believed that truth is to be found not in this world but in the realm of ideas (doctrine of forms) where eternal truths reside. Based on Plato's understanding of truth and knowledge, Ong explains that Platonic ideas are voiceless, immobile, devoid of all warmth, not interactive but isolated, not part of human lifeworld at all but utterly above and beyond it (Ong 1982:80). Such understanding of truth would be foreign to primary oral culture but well accepted in a culture dominated by writing.

Ong's (1982) next trait of oral discourse refers to 'homeostatic versus multiple and historical meaning'. Orality is present-orientated: words have a single meaning

TABLE 1: Attributes of oral and literate cultures.

\begin{tabular}{ll}
\hline Oral/aural & Chirographic \\
\hline Sound and temporality & Sight and space \\
Interiority & Exteriority \\
Incorporating/unifying & Dissecting/isolating \\
\hline Fleeting & Long-lasting \\
Words as event & Words as labels \\
Processual & 'Things' orientated \\
Mnemonics/recollection & Knowledge as stored: looked up \\
Attachment/participatory & Detachment \\
Meaning/utterance always in the context & Autonomous/mobile discourse \\
Grounded in the lifeworld & Abstractions \\
Situational thinking & Deduction/logic (syllogisms) \\
Communal/public & Individualistic/private \\
Dialogue & Monologue \\
Open/dynamic (agonistic) & Closed/fix/static \\
Participation & Distance/objectivity \\
Communication is embodied & Communication is disembodied \\
Time & Space \\
Universal human attribute & Culturally specific technology \\
\hline
\end{tabular}

Source: Adapted from Finnegan, R., 1988, Literacy and orality: Studies in the technology of communication, Blackwell, Oxford. determined by the context in which they are uttered. The meaning of a word is strongly influenced by their immediate existential context. This means that oral cultures tend to throw off past meaning, thereby stabilising the social context. Writing fosters layered meaning as writing is read and re-read outside the context in which it was produced. Also, writing gives us a record of past usages of terms; it fosters a sense of multiple meaning of a word rooted in various historical contexts (Ong 1982:46).

The final attribute of primary oral speech is that of 'communal versus individual identity'. In primarily oral cultures, there is always an immediate audience. Communication always involves the community. The encompassing aspects of sound serve to create communion among speakers and listeners. There is a sense of participation in a common reality, and hence a more communal identity. In orality, there must always be an 'other' present for communication to occur. Writing is isolating and fosters individualism. Writing is often created and read in isolation from others (Ong 1982:102). With writing, there is no real audience present, the writer illusionary imagines or socially constructs the audience he is writing to. Table 1 offers a list of attributes of oral and literate cultures.

Framed by the dichotomy between oral and written, it can be concluded that speech is a cosmic and invisible architecture of the human dark, whereas writing is the visualisation of the acoustic space.

Spoken words are perceived as more emotional than the written word. They are not only oral in form but consist of a combination of the human senses (mouth, ear and eye). The body becomes a social system of communication for the 'Other' through its human sensory to create subversive discourse to undermine the power of the oppressor through speech. We tend to react to each situation that occurs, even to our own act of speaking. The spoken word carries emotion as well as meaning for the 'Other'. Writing then is seen as a more specialist action in which there is a little opportunity or call for reaction (McLuhan 1967).

\section{Conclusion}

In revisiting the thesis of Finnegan 'What is Orality-if anything' has shown that orality and literacy research opens new hermeneutical dimensions in understanding the 'Other' in the context of Post-Apartheid historical development in South Africa. Political orality shows us the relation between speech as power and writing as a privilege in the construction of the political landscape of South Africa. The voices from below and its power to orally denounce and undermine the dominant ideological construction of the Colonial text remains key in the political and educational discourse of power.

In South Africa, there are many primary oral communities and cultures that remain undocumented because of the 
distorted history of the apartheid past. A myriad of historical data documented by the previous establishment reveal their victories and triumphs of the dominant class at the expense of false conscious constructed histories about the historical constructed 'Other'. The oral thought has been interpreted as literate in their expressions and interpretations. Although the spoken word was inscribed in the written text, it will always remain to be a force in the re-order and social construction of the reality of the 'Other'. For primary oral communities, hymns, storytelling, poetry, spiritual songs, testimonies and charismatic preaching by bards, priests as wandering sages, and poets reflect the deeply hidden transcript of primary oral communities in the construction of power and subversive displacing of meaning and representation of reality over against their oppressors.

\section{Acknowledgement Competing interest}

The author has declared that no competing interests exist.

\section{Authors' contributions}

G.P.H. is the sole author of this article.

\section{Ethical consideration}

I hereby confirm as the author of the article submitted to HTS that the following material has not been published in whole or in part elsewhere. The manuscript (mss) is not currently being considered for publication in another journal and I will hold myself individually responsible for its content.

\section{Funding information}

This research received no specific grant from any funding agency in the public, commercial or not-for-profit sectors.

\section{Data availability statement}

Data sharing is not applicable to this article as no new data were created or analysed in this study.

\section{Disclaimer}

The views and opinions expressed in this article are those of the author and do not necessarily reflect the official policy or position of any affiliated agency of the author.

\section{References}

Alessandrini, A.C. (ed.), 1999, Frantz Fanon, critical perspectives, Routledge, London. Argyle, M., 1988, Bodily communication, Routledge, London. Barthes, R., 1972, Mythologies, The Noonday Press, New York.

Baumann, G. (ed.), 1986, The written word, literacy in transition, Clarendon Press, Oxford.

Boehmer, E., 1995, Colonial and postcolonial literature, Oxford University Press, Oxford.
Bringhurst, C., 1992, The elements of typographic style, viewed 18 May 2018, from http://www.etymonline.com/index.php?term=text.

Brown, D., 1995, Orality, textually and history-issues in South African oral poetry and performance, University of Natal, Durban.

Finnegan, R., 1988, Literacy and orality: Studies in the technology of communication, Blackwell, Oxford.

Finnegan, R., 1990, 'What is orality-if anything?', Byzantine Modern Greek Studies 14, 130-149. https://doi.org/10.1179/byz.1990.14.1.130

Foley, R., 1994, 'Words in tradition and words in a text', Semeia 65, 169-177.

Fowler, R.M., 1994, How the secondary orality of the electronic age can awaken us to primary orality of antiquity, viewed 08 July 2018, from http://www.helsinki.fi/ science/optek/1994/n3/fowler.txt.

Fowler, R.M., 2006, From orality to literacy to hypertext: Back to the future?, viewed 08 July 2018, from http://www.bw.edu/ rfowler/pubs/secondoral/oral.html.

Goody, J. \& Watt, I., 1968, 'The consequences of literacy', in Literacy in traditional societies, Comparative Studies in Society and History, vol. 5, No. 3, pp. 304-345, Published by Cambridge University Press.

Goody, J. \& Watt, I., 1968, 'The consequences of literacy', in Literacy in traditional societies, Cambridge University Press, Cambridge.

Goody, J., 1977, The domestication of the savage mind, Cambridge University Press, Cambridge.

Graham, A.W., 1987, Beyond the written word, Cambridge University Press, Cambridge.

Greenfield, P., 1972, 'Oral and written language: The consequences for cognitive development in South Africa, the U.S.A. and England', Language and Speech 15(2), 169-178. https://doi.org/10.1177/002383097201500207

Havelock, E.A., 1963, Preface to Plato, Belknap Press, Cambridge, MA.

Havelock, E.A., 1986, The muse learns to write: Reflections on orality and literacy from antiquity to the present, Yale University Press, New Haven, CT.

Jousse, M., 1997, The anthropology of esture and rhythm, edited by E. Sienaert and transl. collaboration J. Connolly, Centre for Oral Studies, University of Natal, Durban.

Kelber, W.H., 1994, 'Jesus and tradition, words in time, words in space', Semeia 65(1994), 139-167.

Kruger, G., 1992, 'Historical patterns of writing and literacy in South Africa: Neither destroyed orality nor incomplete literacy', Comparative Studies in Society and History 33, 225-254. https://doi.org/10.1017/S0010417500017023

Lévi-Strauss, C., 1962, The savage mind, Weidenfeld and Nicolson, London.

Lord, A.B., 1960, The singer of tales, Harvard University Press, Cambridge, MA.

McLuhan, M., 1962, The Gutenberg Galaxy: The making of typographic man, University of Toronto Press, Toronto.

McLuhan, M., 1967, The spoken word flower of evil?, viewed 08 July 2018, from http://digitallantern.net/mcluhan/course/spring96/spokenword.html.

McLuhan, M., 2005, Understanding Media, Routledge, London.

Meer, F., 1989, Resistance in the townships, Madiba Publications, Durban.

Miller, C.L., 1990, Theories of Africans, University of Chicago Press, Chicago, IL.

Naas, M., 2010, 'Earmarks: Derrida's reinvention of philosophical writing in "Plato's Pharmacy"', in M. Leonard (ed.), Derrida and antiquity, pp. 43-72, Oxford University Press, London.

Narismula, G.P., 1998, Locating the popular-democratic in South African resistance literature in English, 1970-1990, University of Durban Westville, Durban.

Ong, W.J., 1982, Orality and literacy. The technologizing of the word, Methuen, New York.

Ong, W.J., 1987, 'Orality-literacy studies and the unity of the human race', Oral Tradition 2(1), 371-382.

Ong, W.J., 1995, 'Hermeneutics forever: Voice, text, digitization, and the I', Oral Tradition 10(1), 3-26.

Rubin, D.C., 1995, Memory in oral traditions, Oxford University Press, Oxford.

Rutkus, M., 2014, Thucydides and the writing of history, viewed 20 July 2018, from http://www.welchco.com/02/14/01/60/99/11/0801.HTM

Schipper, M., 1989, Beyond the boundaries, African literature and literary theory, Allison \& Busby, London.

Selden, R., 1985, A reader's guide to contemporary literary theory, Harvester, Brighton, London.

Smith, L.T., 1999, Decolonizing methodologies, Biddles Ltd, London.

Scott, J., 1990, Domination and the arts of resistance; hidden transcripts, Yale University Press, New Haven, CT.

Tannen, D., 1982, Spoken and written language, Ablex Publishers, Norwood, NJ.

Waugh, R., 1995, 'Word, breath, and vomit: Oral competition in old English and old Norse literature', Oral Tradition 10(2), 359-386.

Wikipedia Contributors, 2019, Phaedrus [online], Wikipedia, viewed 14 August 2019, from https://en.wikipedia.org/wiki/Phaedrus 